\title{
KANDUNGAN TERPENOID DALAM DAUN ARA (Ficus carica L.) SEBAGAI AGEN ANTIBAKTERI TERHADAP BAKTERI Methicillin-Resistant Staphylococcus aureus
}

\author{
Endang Dwi Wulansari ${ }^{1)}$, Dewi Lestari ${ }^{1)}$, Mujahidah Asma Khoirunissa ${ }^{1)}$ \\ ${ }^{1)}$ STIFAR "Yayasan Pharmasi Semarang", Semarang, Jawa Tengah
}

\begin{abstract}
Fig leaves (Ficus carica L.) are known to the public with many health benefits. The content of efficacious compounds in fig leaves such as terpenoids has potential as an antibacterial and needs to be known. This study aims to determine the antibacterial activity of terpenoid content in extracts and fractions of fig leaves (Ficus carica L.) on the growth of MethicillinResistant Staphylococcus aureus (MRSA) bacteria by contact bioautography. Extraction was carried out by stratified soxhletation with $n$-hexane and ethyl acetate. Separation was carried out by coloum vacuum liquid chromatography (VLC) method. The wells diffusion method is used as the antibacterial activity test, while the TLC contact bioautography test is carried out to determine the antibacterial activity of the terpenoid content in the extracts and fractions. Extracts of n-hexane, ethyl acetate, and ethanol of fig leaf (Ficus carica L.) have antibacterial activity against MRSA with a diameter of inhibitory zone $0.111 \pm 0.003 ; 0.328$ $\pm 0.026,1.044 \pm 0.115 \mathrm{~cm}$, and show significant differences. Extracts of $n$-hexane, ethyl acetate, and ethanol of fig leaf (Ficus carica L.) contain terpenoids. The fraction of ethyl acetate and ethanol extracts of fig leaves (Ficus carica L.) contains terpenoid compounds which can provide antibacterial activity against MRSA by TLC contact bioautography.
\end{abstract}

Keywords: fig leaves, Ficus carica L., antibacterial, Methicillin-Resistant S. aureus.

\begin{abstract}
ABSTRAK
Daun ara (Ficus carica L.) dikenal masyarakat dengan banyak manfaat dalam bidang kesehatan. Kandungan senyawa berkhasiat dalam daun ara seperti terpenoid berpotensi sebagai antibakteri dan perlu diketahui. Penelitian ini bertujuan untuk mengetahui aktivitas antibakteri kandungan terpenoid dalam ekstrak maupun fraksi daun ara (Ficus carica L.) terhadap pertumbuhan bakteri Methicillin-Resistant Staphylococcus aureus (MRSA) secara KLT bioautografi kontak. Ekstraksi dilakukan dengan cara soxhletasi bertingkat dengan pelarut n-heksana dan etil asetat. Pemisahan dilakukan dengan metode kromatografi kolom vakum cair (KVC). Uji aktivitas antibakteri menggunakan metode difusi sumuran, sedangkan uji bioautografi kontak dilakukan untuk mengetahui aktivitas antibakteri kandungan terpenoid dalam ekstrak dan fraksi. Ekstrak n-heksana, etil asetat, dan etanol daun ara (Ficus carica L.) mempunyai aktivitas antibakteri terhadap MRSA dengan diameter zona hambat berturut-turut $0,111 \pm 0,003 ; 0,328 \pm 0,026,1,044 \pm 0,115 \mathrm{~cm}$, dan menunjukkan perbedaan signifikan. Ekstrak n-heksana, etil asetat, dan etanol daun ara (Ficus carica L.) mengandung terpenoid. Fraksi dari ekstrak etil asetat dan etanol daun ara (Ficus carica L.) mengandung senyawa terpenoid yang dapat memberikan aktivitas antibakteri terhadap MRSA secara KLT bioautografi kontak.
\end{abstract}

Kata kunci : daun ara, Ficus carica L., antibakteri, Methicillin-Resistant S. aureus. 


\section{PENDAHULUAN}

Infeksi yang disebabkan oleh Methicillin-Resistant Staphylococcus aureus (MRSA) mengalami peningkatan, di Asia prevalensi infeksi MRSA mencapai $70 \%$, sementara di Indonesia pada tahun 2006 berada pada angka 23,5\% (Sulistyaningsih, 2010). MRSA sendiri dapat disebabkan oleh paparan terapi antibiotik golongan beta laktam yang tidak rasional (Nurkusuma, 2009). Resistensi bakteri yang terjadi menuntut adanya penemuan dan pengembangan bahan alam sebagai antibakteri.

Perkembangan penelitian bahan alam sebagai antibakteri menunjukkan bahwa terdapat tanaman yang berpotensi sebagai agen antibakteri. Ara (Ficus carica L.) merupakan salah satu tanaman yang berpotensi sebagai antioksidan, antivirus, anthelmintik, serta antibakteri (Joseph dan Raj, 2011). Ekstrak daun ara (Ficus carica L.) menunjukkan aktivitas antibakteri terhadap pertumbuhan beberapa bakteri oral seperti Streptococcus mutans, Streptococcus sanguinis, Streptococcus sobrinus, Streptococcus ratti, Streptococcus criceti, Streptococcus anginosus, Streptococcus gordonii, Aggregatibacter actinomycetemcomitans, Fusobacterium nucleatum, Prevotella intermedia, Porphyromonas gingivalis (Jeong dkk., 2009), serta bakteri Staphylococcus aureus, Bacellus cereus (Mahmoudi dkk, 2016), Klebsiella pneumonae, Pseudomonas aeruginosa, Salmonella typhi, dan Escherichia coli (Rashid dkk., 2014).

Ekstrak daun ara (Ficus carica L.) mengandung senyawa fenolik terutama flavonoid (Salem dkk., 2013), terpenoid seperti komponen dalam minyak atsiri (Ayoub dkk., 2010) juga triterpenoid (Mohan dkk., 2007), steroid dan kumarin (Kalaskar dkk., 2010). Kandungan terpenoid dalam daun ara merupakan komponen yang berpotensi sebagai antibakteri, sehingga akan dihasilkan agen antibakteri yang juga mampu menghambat pertumbuhan bakteri yang resisten terhadap antibiotik yang ada. Mekanisme kerja senyawa terpenoid sebagai zat antibakteri dengan melibatkan kerusakan membran oleh senyawa lipofilik. Terpenoid dapat bereaksi dengan porin (protein transmembran) pada membran luar dinding sel bakteri, membentuk ikatan polimer yang kuat dan merusak porin, mengurangi permeabilitas dinding sel bakteri sehingga sel bakteri kekurangan nutrisi, pertumbuhan bakteri terhambat atau mati (Retnowati, 2011).

Penelitian awal diperlukan untuk mengetahui senyawa terpenoid dalam daun ara (Ficus carica L.) yang berpotensi antibakteri, terutama untuk mendapatkan fraksi yang mengandung terpenoid aktif antibakteri MRSA. Skrinning awal terhadap senyawa aktif antibakteri dapat dilakukan dengan uji KLT bioautografi kontak (Paputungan dkk., 2019; Aslah dkk., 2019). Uji KLT bioautografi kontak dapat digunakan untuk mengetahui golongan senyawa tertentu di dalam ekstrak yang mempunyai aktivitas antibakteri.

\section{METODOLOGI PENELITIAN Persiapan bahan}

Bahan penelitian berupa daun ara (Ficus carica L.), diperoleh dari daerah Gunung Pati, Semarang, Jawa Tengah, pada bulan Maret 2018. Daun ara dikeringkan dengan lemari pengering pada suhu $50^{\circ} \mathrm{C}$ dan dihaluskan. Serbuk diayak dengan ayakan 30/40.

\section{Ekstraksi}

Serbuk daun ara sebanyak 150 gram diekstraksi dengan cara soxhletasi menggunakan pelarut $n$-heksana sebanyak $400 \mathrm{~mL}$. Di akhir soxhletasi, serbuk yang digunakan, diekstraksi kembali dengan pelarut etil asetat $(400 \mathrm{~mL})$. Serbuk yang diperoleh setelah ekstraksi dengan pelarut etil asetat, dilakukan ekstraksi kembali dengan pelarut etanol (400 mL). Masingmasing ekstrak yang diperoleh, dipekatkan 
menggunakan penguap vakum berputar, sehingga diperoleh ekstrak n-heksana, ekstrak etil asetat, dan ekstrak etanol kental. Ekstrak kental yang diperoleh, dihitung rendemen dan dilakukan pengujian untuk mengetahui kandungan terpenoid dengan cara KLT.

Uji KLT terhadap ekstrak dilakukan dengan fase diam silica gel GF $254 \mathrm{~nm}$ dan fase gerak toluen : etil asetat (93:7); toluen : kloroform : etanol (4:4:1); dan kloroform : metanol : air (7:3:4). Penampak bercak yang digunakan adalah anisaldehid-asam sulfat untuk deteksi umum senyawa golongan terpenoid, dan pereaksi darah untuk deteksi senyawa saponin (Wagner dkk., 1996).

\section{Uji Resistensi Antibiotik Bakteri MRSA}

Methicillin-resistant Staphylococcus aureus (MRSA) mengalami kekebalan terhadap antibiotik jenis metisilin (Hardana, 2005). Oleh karena ini diperlukan uji untuk mengetahui kepekaan bakteri MRSA terhadap antibiotik. Uji resistensi antibiotik bakteri MRSA yang digunakan dilakukan dengan menggunakan ampisilin dan amoksisilin konsentrasi 1; 1,5; dan 2\%.) Hasil uji menunjukkan bakteri MRSA yang digunakan telah mengalami resisten terhadap antibiotik $\beta$-laktam (ampicillin dan amoxicillin), sehingga pada penelitian ini digunakan siprofloksasin sebagai kontrol positif pada uji aktivitas antibakteri.

\section{Uji Aktivitas Antibakteri Metode Difusi Sumuran}

Metode yang digunakan untuk pengujian antibakteri adalah metode sumuran dengan media Manitol Salt Agar (MSA) (Benmansour dkk., 2016) yang sudah diinokulasi bakteri MRSA. Konsentrasi bakteri menggunakan standar $1 / 2 \mathrm{Mc}$ Farland yang mempunyai kekeruhan setara dengan $1,5 \times 10^{8} \mathrm{CFU} / \mathrm{mL}$ (Soraya dkk., 2018). Sampel uji berupa ekstrak $n$ heksana, etil asetat, dan etanol daun ara
(Ficus carica L.) dengan konsentrasi $50 \%$ dalam pelarut DMSO. Siprofloksasin $0,05 \%$ digunakan sebagai kontrol positif dan DMSO sebagai kontrol negatif. Media yang telah diveri perlakuan kemudian diinkubasi pada suhu $37^{\circ} \mathrm{C}$ selama 24 jam. Hasil pengujian aktivitas antibakteri ditunjukkan berupa diameter zona bening yang diukur menggunakan jangka sorong. Uji dilakukan enam kali replikasi.

Analisis data berupa diameter zona bening dari ekstrak $n$-heksana, etil asetat, dan etanol daun ara (Ficus carica L.) diuji secara statistika menggunakan SPSS versi 19.0. Data diuji distribusi normal dan homogenitas, kemudian diuji beda menggunakan Anova satu jalan.

\section{Fraksinasi}

Fraksinasi dalam penelitian ini dilakukan terhadap ekstrak etil asetat dan etanol daun ara (Ficus carica L.). Ekstrak etil asetat dan etanol kental masing-masing dilakukan fraksinasi dengan cara kromatografi kolom vakum cair (KVC). Fase diam yaitu silika gel $\mathrm{GF}_{254}$ dan fase gerak yang digunakan adalah n-heksana : etil asetat dengan perbandingan tertentu.

Sebanyak 12 fraksi diperoleh dari masing-masing ekstrak yang dilakukan pemisahan dengan KVC. Masing-masing fraksi diuji KLT untuk mengetahui kandungan terpenoid, dan diuji KLT bioautografi kontak untuk mengetahui senyawa terpenoid yang mempunyai aktivitas antibakteri MRSA.

\section{Uji KLT Bioautografi Kontak}

Ekstrak dan fraksi daun ara dilakukan uji bioautografi kontak. Ekstrak dan fraksi ditotolkan pada lempeng KLT silika gel GF $254 \mathrm{~nm}$ dan dielusi menggunakan eluen yang sesuai untuk senyawa terpenoid. Lempeng silika dikeringkan, dan ditempelkan selama 30 menit pada $40 \mathrm{ml}$ media MSA yang telah diinokulasikan $1,00 \mathrm{ml}$ suspensi bakteri MRSA, kemudian diambil lempeng silika gel. Media MSA diikubasi pada suhu $37^{\circ} \mathrm{C}$ 
selama 24 jam dan dianalisis zona hambat yang terbentuk.

\section{HASIL DAN PEMBAHASAN}

Rendemen berupa hasil ekstraksi yang menunjukkan banyaknya senyawa yang tersari dalam pelarut yang dihasilkan (Setyaningtyas, 2017). Rendemen ekstrak yang diperoleh dengan pelarut n-heksana, etil asetat, dan etanol daun ara berturutturut sebesar 4,01; 6,68; dan 10,21\%. Ekstrak n-heksana, etil asetat, dan etanol daun ara mengandung senyawa terpenoid seperti ditunjukkan di Gambar 1.

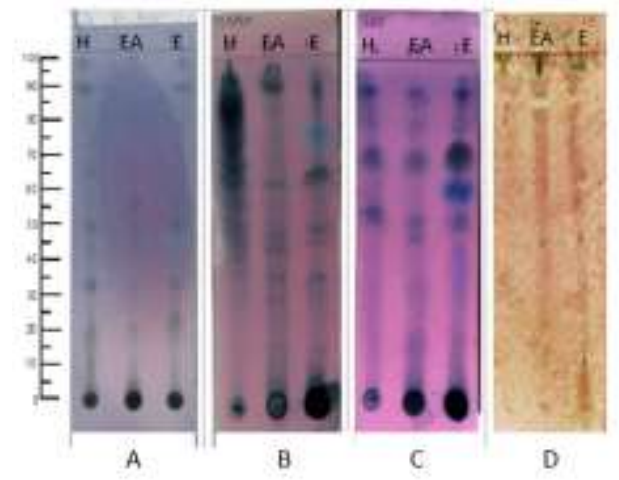

Gambar 1. Hasil KLT Ekstrak n-Heksana (H), Etil asetat (EA), dan Etanol (E)

Kromatogram A menggunakan fase gerak toluen : etil asetat (93:7) dan penampak bercak anisaldehid-asam sulfat, ketiga ekstrak menunjukkan beberapa kandungan senyawa terpenoid dengan warna bercak merah ungu dan biru ungu. Begitu juga kromatogram $B$ dengan fase gerak toluen : kloroform : etanol (7:3:4), dan kromatogram $\mathrm{C}$ dengan fase gerak kloroform : metanol : air (4:4:1). Terpenoid dapat tersari dalam pelarut non polar maupun polar. Terpenoid dalam bentuk glikosida akan dapat tersari dalam pelarut semi polar ataupun polar. Kandungan senyawa saponin terdapat dalam ekstrak etil asetat dan etanol, diketahui dari hasil positif bercak putih kekuningan dengan latar belakang merah muda setelah disemprot dengan penampak bercak darah (kromatogram D) (Wagner dkk., 1996).

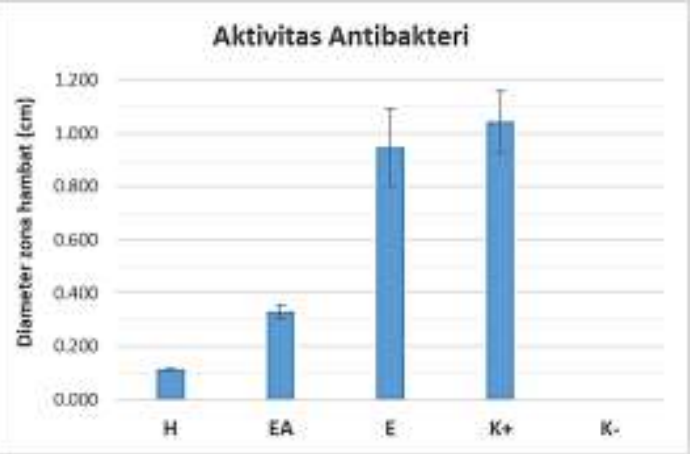

Gambar 2. Aktivitas antibakteri Ekstrak nHeksana, Etil asetat, dan Etanol Daun Ara (Ficus carica)

Uji aktivitas antibakteri ekstrak nheksana (H), etil asetat (EA), dan etanol (E) daun ara menunjukkan bahwa pada konsentrasi $50 \%$ masing masing sampel memberikan diameter zona hambat berturut-turut $0,111 \pm 0,003 ; 0,328 \pm 0,026$, dan $1,044 \pm 0,115 \mathrm{~cm}$ (Gambar 2.). Menurut Nirwana, dkk. (2018), ekstrak etanol daun ara menunjukkan aktivitas antibakteri terhadap salah satu bakteri oral yaitu Enterococcus faecalis pada konsentrasi $50 \%$. Konsentrasi $50 \%$ sudah menunjukkan tidak ada pertumbuhan bakteri. Ekstrak etil asetat kasar dari daun ara berpotensi dalam menghambat pertumbuhan Staphylococcus aureus, lebih baik dari ekstrak metanol kasar (Weli dkk., 2015). Hal ini menunjukkan bahwa ekstrak daun ara dapat memberikan aktivitas antibakteri baik kuat ataupun moderat terhadap beberapa jenis bakteri, baik gram positif maupun gram negatif.

Uji anava satu jalan menunjukkan perbedaan antar kelompok (sig. $0,000<0,05)$. Hasil uji pasca anava dengan LSD, menunjukkan perbedaan signifikan antar kelompok, namun kelompok etanol menunjukkan perbedaan signifikan dengan kontrol positif yang digunakan (sig. 0,09>0,05). Hal tersebut dikarenakan perbedaan kandungan senyawa dalam ekstrak $n$-heksana, ekstrak etil asetat dan ekstrak etanol sehingga kemampuan 
sampel dalam menghambat bakteri juga berbeda. Beberapa kandungan senyawa dalam daun ara telah diketahui berpotensi terhadap bekteri. Kandungan flavonoid seperti rutin, kuersetin, dan luteolin; asam fenolat seperti asam ferulat; fitosterol seperti toraxasterol; serta kandungan kumarin dalam buah ara dilaporkan berpotensi sebagai antibakteri (Aref dkk., 2011). Identifikasi kandungan senyawa terpenoid belum pernah dilaporkan dalam daun ara. Kandungan senyawa tersebut mempunyai sifat kelarutan yang berbeda, sehingga dimungkinkan tersari dalam pelarut ektraksi yang berbeda. Di dalam penelitian ini diperoleh bahwa ekstrak etanol memberikan aktivitas antibakteri terbesar dibanding dengan ekstrak nheksana dan etil asetat.

Uji bioautografi kontak dilakukan terhadap golongan senyawa terpenoid pada ekstrak $n$-heksana, etil asetat, dan etanol daun ara untuk mengetahui fraksi dengan kandungan terpenoid yang berpotensi sebagai antibakteri terhadap bakteri MRSA. Kandungan senyawa terpenoid dalam ekstrak etil asetat dan ekstrak etanol menunjukkan aktivitas antibakteri secara bioautografi kontak terhadap bakteri MRSA. Terpenoid yang terkandung dalam ekstrak n-heksana tidak menunjukkan aktivitas antibakteri terhadap MRSA, yang dapat dimungkinkan karena senyawa yang kurang berpotensi sebagai antibakteri ataupun konsentrasi senyawa tersebut yang kecil dalam ekstrak.

Mekanisme kerja triterpenoid dengan cara bereaksi dengan porin pada membran luar dinding sel bakteri, membentuk ikatan polimer yang kuat sehingga mengurangi permeabilitas dinding sel bakteri. Mekanisme kerja saponin sebagai antibakteri yaitu dapat menyebabkan kebocoran protein dan enzim dari dalam sel (Retnowati dkk., 2011).

Pemisahan terhadap ekstrak daun ara untuk dilakukan fraksinasi digunakan ekstrak etil asetat yang menunjukkan bahwa golongan senyawa triterpenoid memiliki aktivitas antibakteri secara bioautografi kontak. Merujuk pada hasil KLT pada ekstrak etil asetat, yang menunjukan perubahan warna pada saat disemprot dengan anisaldehid asam sulfat menjadi biru keunguan yang mengarah pada senyawa triterpenoid (Wagner,1996).

Lebih lanjut, dalam penelitian ini dihasilkan masing-masing 12 fraksi dari ekstrak etil asetat dan ekstrak etanol daun ara dengan metode KVC. Uji KLT bioautografi kontak terhadap 12 fraksi aktif dari ekstrak etil asetat daun ara diketahui bahwa terdapat senyawa terpenoid yang berpotensi sebagai antibakteri MRSA dalam fraksi 2 (EA.F2) dan fraksi 5 (EA.F5). Fraksi yang dihasilkan dari KVC ekstrak etanol menunjukkan hasil positif senyawa terpenoid yang berpotensi sebagai antibakteri MRSA dalam fraksi 2 (E.F2) dan fraksi 8 (E.F8).

Uji KLT bioautografi kontak fraksi EA.F2 menggunakan hasil KLT dengan fase gerak toluene : etil asetat (93:7), bercak berwarna biru ungu dengan penampak bercak anisaldehid asam sulfat pekat $(\mathrm{Rf} 0,97)$ menunjukkan zona hambat pertumbuhan bakteri MRSA. Berbeda dengan fraksi EA.F2, uji KLT bioautografi kontak EA.F5 menggunakan fase gerak dengan polaritas berbeda yaitu klorofom : metanol : air (7:3:4). Bercak berwarna biru ungu dengan penampak bercak anisaldehid asam sulfat pekat $(\operatorname{Rf} 0,72)$ menunjukkan zona hambat pertumbuhan bakteri, mengarah pada bentuk triterpenoid (Wagner dkk., 1996). Ekstrak etil asetat mengandung dua senyawa terpenoid yang berpotensi sebagai antibakteri terhadap pertumbuhan bakteri MRSA.

Uji KLT bioautografi kontak fraksi E.F2 dan E.F8 menggunakan hasil KLT dengan fase gerak toluen : kloroform : etanol (4:4:1), bercak berwarna biru ungu dengan penampak bercak anisaldehid asam sulfat pekat mempunyai harga Rf berturutturut 0,9 dan 0,43 ; menunjukkan zona 
hambat pertumbuhan bakteri MRSA. Bercak E.F8 dengan Rf 0,43 juga menunjukkan hasil positif dengan penampak bercak darah, sehingga mengarah pada bentuk senyawa saponin karena kemampuannya menghemolisis darah. Ekstrak etanol mengandung dua senyawa terpenoid yang berpotensi sebagai antibakteri terhadap pertumbuhan bakteri MRSA, mengarah pada bentuk triterpenoid dan saponin.

\section{KESIMPULAN}

Kandungan terpenoid dalam daun ara (Ficus carica L.) berpotensi sebagai antibakteri terhadap pertumbuhan bakteri MRSA, kandungan terpenoid tersebut mengarah pada bentuk triterpenoid.

\section{SARAN}

Perlu dilakukan isolasi lebih lanjut terhadap hasil fraksi yang mempunyai aktivitas antibakteri pada daun ara serta senyawa aktif yang mempunyai aktivitas antibakteri dalam ekstrak. Pengembangan dalam bentuk sediaan farmasi yang sesuai juga perlu dilakukan untuk mendapatkan sediaan antibakteri dengan senyawa antibakteri alami.

\section{DAFTAR PUSTAKA}

Aref H.L., Mars M., Fekih A., Aouni M., Said K. 2012. Chemical Composition and Antibacterial Activity of a Hexane Extract of Tunisian Caprifig Latex from The Unripe Fruit of Ficus carica. Pharmaceutical Biology. 50(4): 407-412 DOI: 10.3109/13880209.2011.608192

Aslah A.P., Lolo W.A., Jayanto I. 2019. Aktivitas Antibakteri dan Analisis KLT-Bioautografi Dari Fraksi Daun Mengkudu (Morinda citrifolia L.). PHARMACONJurnal Ilmiah Farmasi-UNSRAT. 8(3): 89-99
Ayoub N., Singab A.N., Mostafa N., Schultze W. 2010. Volatile Constituents of Leaves of Ficus carica Linn. Grown in Egypt. Journal of Essential Oil Bearing Plants. 13(3): 316-321, DOI: 10.1080/0972060X.2010.10643827

Benmansour N., Benmansour A., El hanbali F., Gonzales-Mas, Blazquez M.A., El Hakmaoui A., Akssira M. 2016. Antimicrobial Aactivity of Essential Oil of Artemisia judaica L. from Algeria Against Multi-drug Resistant Bacteria from Clinical Origin. Flavour Fragr.J. 31:137142. DOI: $10.1002 / f f j .3291$

Jeong M.R., Kim H.Y., Cha J.D. 2009. Antimicrobial Activity of Methanol Extract from Ficus carica Leaves Against Oral Bacteria. Journal of Bacteriology and Virology. 39(2): 97-102.

DOI: 10.4167/jbv.2009.39.2.97

Joseph B., Raj K. 2011. Pharmacognostic and Phytochemical Properties of Ficus carica Linn. - An Overview. International Journal of Pharmtech Research. 3(1): 08-12

Kalaskar M.G., Shah D.R., Raja N.M., Surana S.J., Gond N.Y. 2010. Pharmacognostic And Phytochemical Investigation of Ficus carica Linn. Ethnobotanical Leaflets. 14: 599-609.

Mahmoudi S., Khali M., Benkhaled A., Benamirouche K., Baiti I., 2016. Phenolic And Flavonoid Contents, Antioxidant And Antimicrobial Activities Of Leaf Extracts From Ten Algerian Ficus carica L. Varieties. Asian Pacific Journal of Tropical Biomedicine. DOI: 10.1016/j.apjtb.2015.12.010 
Mohan K., Pallavi E., Kumar R., Ramesh M., Venkatesh S. 2007. Hepatoprotective Activity of Ficus carica Linn. Leaf Extract Against Carbon Tetrachloride-induced Hepatotoxicity in Rats. DARU. 15(3): 162-166

Nurkusuma, D.D. 2009. Faktor Yang Berpengaruh Terhadap Kejadian Methicillin resistant Staphylococcus aureus Pada Kasus Infeksi Luka Pasca Operasi Di Ruang Perawatan Bedah Rumah Sakit Dokter Kariadi Semarang. Thesis. Semarang: Fakultas Pasca Sarjana Magister Ilmu Biomedik dan Program Pendidikan Dokter Spesialis-I Ilmu Bedah. Universitas Diponegoro

Paputungan A.N., Lolo W.A., Jayanto I. 2019. Aktivitas Antibakteri dan Analisis KLT-Bioautografi Dari Fraksi Daun Manggis (Garcinia mangostana L.). PHARMACONJurnal Ilmiah Farmasi-UNSRAT. 8(3): 109-118

Rashid K.I., Mahdi N.M., Alwan M.A., Khalid L.B. 2014. Antimicrobial Activity Of Fig (Ficus carica Linn.) Leaf Extract As Compared With Latex Extract Against Selected Bacteria And Fungi. Journal of Babylon University. 5 (22) : 16201626.

Retnowati Y., Bialangi N., Posangi N.W. 2011. Pertumbuhan Bakteri Staphylococcus aureus Pada Media Yang Diekspos Dengan Infus Daun Sambiloto (Andrographis paniculata). Saintek. 6(2)

Salem M.Z.M., Salem A.Z.M., Camacho L.M., Ali H.M. 2013. Antimicrobial
Activities And Phytochemical Composition Of Extract Of Ficus Species: An Over view. African Journal Of Microbiology Research. 7(33): 4207-4219. DOI: 10.5897/AJMR2013.5570

Setyaningtyas A., Dewi I. K., dan Winarso A. 2017. Potensi Antioksidan Ekstrak Etil Asetat Biji Dan Kulit Petai (Parkia speciosa Hassk.). Jurnal KesMaDaSka. Januari 2017: 47-56

Soraya C., Chismirina S., dan Novita R. 2018. Pengaruh Perasan bawang Putih (Allium sativum L.) Sebagai Bahan Irigasi Saluran Akar Dalam Menghambat Pertumbuhan Enterococcus faecalis Secara Invitro. Cakradonya Dental Journal. 10(1): 1 $-9$

Sulistyaningsih, 2010. Uji Kepekaan Beberapa Sediaan Antiseptik Terhadap Bakteri Staphylococcus aureus dan Staphylococcus aureus Resisten Metisilin (MRSA). Laporan Penelitian Mandiri. Bandung: Fakultas Farmasi. Universitas Padjajaran.

Wagner, H., Bladt S., Zgainski E.M. 1996. Plant Drug Analysis "A Thin Layer Chromatography Atlas”. New York : Springer.

Weli A.M., Al-Blushi A.A.M., Hossain M.A. 2015. Evaluation of Antioxidant and Antimicrobial Potential of Different Leaves Creude Extract of Omani Ficus carica Against Food Borne Pathogenic Bacteria. Asisn Pasific Journal of Tropical Disease. 5(1): 13-16. DOI: 10.1016/S2222-1808(14)60619-8 